\title{
А. А. Сазонова
}

\section{ЛЕВШЕСТВО: ЛЮДИ И КОШКИ. СРАВНИТЕЛЬНЫЙ АНАЛИЗ}

\begin{abstract}
Аннотация. Левшество, связано с асимметрией парных органов человека. Благодаря принципу биологической надежности человек наделен многими органами, дублирующими самих себя. У него пара легких, пара почек, пара глаз, пара рук, пара ног и т.д. Если один из парных органов отказывает, другой может частично принимать на себя его функиии. Но полное дублирование природа, видимо, сочла роскошью. Как показывают наблюдения и эксперименты, парные органы у людей развиты неодинаково. Один из двух парных органов всегда является доминирующим. Преобладание левой части над правой и называется левществом.

Праворукий мир людей - зеркально противоположен миру левщей. Левщам очень не просто приспосабливаться к миру, в котором все создано только для правшей. Итак, мы предполагаем, что поскольку кошки, семейство Felidae, и люди... относятся к одному царству животных, классу высших позвоночных - млекопитающих, то, возможно, существует общее и особенное в леволапости у кошек и леворукости у людей. Которые должны проявляться в психодинамике поведения.
\end{abstract}

Ключевые слова: сочиология, левщество, леворукость, леволапость, психодинамика, антропоцентризм, толерантность, люди, кошки, ассиметрия.

- Как тебя понимать? Понимать меня необязательно. Обязательно любить и кормить вовремя. Чеширский Kom

$\mathrm{B}$ природе левизна и правизна - мало изученный феномен, хотя асимметрия - одно из фундаментальных свойств природы.

Известно, что живая клетка по своему строению асимметрична, а мертвая - симметрична. Наблюдения Луи Пастера в XIX веке сводились к тому, что многие органические молекулы могут образовывать две различающиеся формы, которые представляют собой зеркальное отражение - таким же точно образом, как перчатка правой руки есть зеркальное повторение перчатки для левой. Будучи химически идентичными, такие молекулы различаются морфологически, их называют стереоизомерами.

Спираль молекулы ДНК неизменно закручена в левую сторону. И хотя все люди внешне выглядят симметрично, все они обладают скрытой односторонностью, не имеющей ничего общего с тем, правша, данный человек или левша. Так, почти у всех нас сердце расположено с левой стороны, а печень - справа. Под своими кожными покровами мы весьма асимметричны.

1 Льюис Кэрролл, «Приключения Алисы в Стране Чудес», http://lib.ru/CARROLL/alisa.txt
Для биологических форм, однако, характерно наличие исключений. На десять тысяч человек встречается один, у которого расположение внутренних органов перевернуто. Это явление по-латыни называется «ситус инверсус». Доктор Найджел Браун из медицинской школы-больницы Сент-Джордж, написавший работу о «ситус инверсус», убежден, что асимметричность тела, в конечном счете, определяется левой или правой морфологией химических строительных блоков жизни, хотя и признает, что связать напрямую молекулу и млекопитающее пока не представляется возможным. Доктор Браун считает, что существует некий химический спусковой механизм, который как-то сообщает человеческому зародышу в возрасте пятнадцати дней, что есть левое, а что - правое.

Физики давно установили, что наша Вселенная асимметрична. В ней все (от спиралей ДНК и морских раковин до галактик) закручено в одну сторону. Согласно теории Эйнштейна - Картана, это связано со свойствами пространства-времени нашего мира. Даже человеческая мысль, как утверждают современные исследователи, обладает торсионными свойствами (от слова “торсион” - вращение). Но, по словам физиков, существует и “зеркальная (относительно нас) Вселенная”, закрученная в другую сторону. 


\section{Политика и общество - №6(90) • 2012}

Этот “параллельный мир”, где время течет по-иному, может иногда соприкасаться с нашим. Возможно, что влияние этого “зазеркалья" и определяет появление леворуких людей, способных к ясновидению. Торсионное поле их мыслей способно проникать в будущее благодаря другому вектору вращения. Существует гипотеза, что на нашей планете идет скрытая экспансия левшей, которые, сами того не подозревая, являются эмиссарами чуждой нам Вселенной, потомками леворуких пришельцев, посетивших когда-то Землю. Ведь только законы иного пространства могли породить “зеркальные гены”, дающие иную ориентировку и телу, и мыслям...

\section{Анализ знаний о явлении левшества}

Левши составляют 10-17 процентов населения нашей планеты. В 1930-е годы в Великобритании насчитывалось около 3\% левшей, к 1950-м годам их стало около 5\%, а сейчас примерно каждый десятый англичанин - левша. В России, соответственно, их порядка 15-18 миллионов человек. Причем их число растет год от года - с тех пор как народное образование оставило, наконец, непохожих учеников в покое.

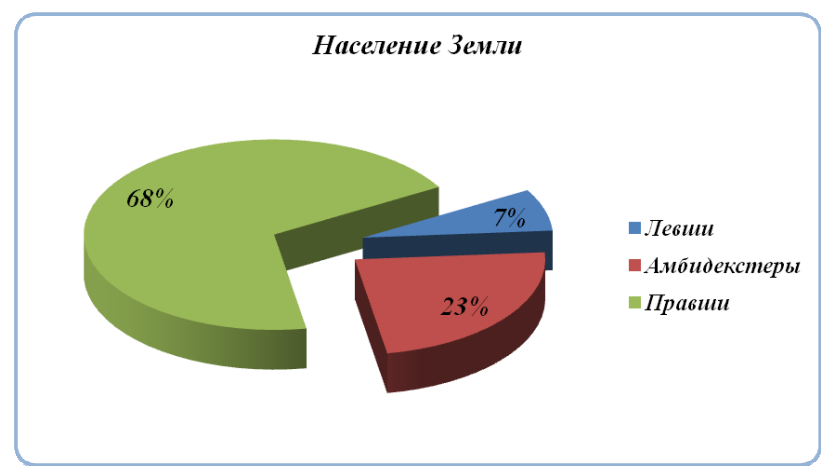

Диаграмма 1. Левши в Мире

Доподлинно известно следующее: среди детей праворуких родителей левши составляют примерно 2 процента, если один родитель праворук - 17 процентов, у двух левшей - 46 процентов. В мире насчитывается примерно 9-11 процентов леворуких детей, но в нашей стране - почти 25 процентов.

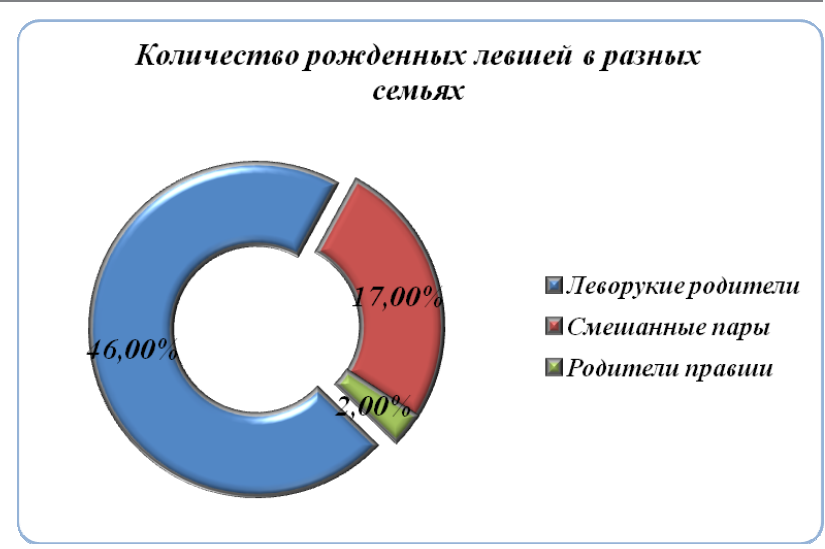

Диаграмма 2. Вероятность появления левшей в разных семьях

Если в творческой сфере процент леворуких и амбидекстров достаточно велик, то среди представителей технических профессий явно преобладают правши.

Национальное Бюро Экономических Исследований Соединенных Штатов Америки опубликовало любопытный доклад о превосходстве левшей над правшами. Как оказалось, выпускники высших учебных заведений, у которых более развита левая рука, зарабатывают на $13 \%$ - 21\% (в зависимости от продолжительности обучения) больше, чем их однокашники - правши.

Исследовательские работы специалистов Колледжа Лафайет и Университета Джона Хопкинса свидетельствуют, что левши чаще, чем правши, становятся высококлассными специалистами (53\% против 38\%). Левшей также непропорционально много среди художников, музыкантов и некоторых категорий спортсменов (например, бейсболистов, гольферов и боксеров).

Среди населения Южной Азии, Восточной Европы, Юго-восточной Азии встречается намного больше левшей, чем в других этнических группах во всем мире, в то время как среди населения Западной и Северной Европы,

Африки - левшей встречается намного меньше. 


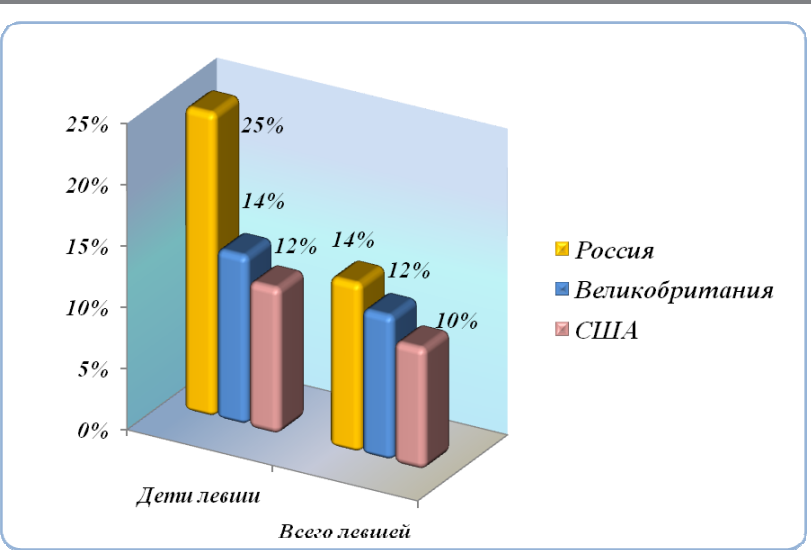

Диаграмма 3. Распределение левщей по странам, в том числе детей

Исследования, проведенные в Мичиганском университете, выявили, что у левшей преобладают такие показатели темперамента, как эмоциональность, осторожность, конформность, а так же совестливость, робость, эстетическая впечатлительность, чувственность.

Знаменитые левши:

Политики и военные: Гай Юлий Цезарь, Александр Македонский, Жанна Д’Арк, Карл Великий, Наполеон Бонапарт, Отто Бисмарк, Бенджамин Франклин, Уинстон Черчилль, Рональд Рейган, Джорж Буш Старший, Билл Клинтон, Фидель Кастро, Махатма Ганди, Королева Виктория, Барак Обама

Ученые и бизнесмены: Леонардо да Винчи, Альберт Эйнштейн, Исаак Ньютон, Никола Тесла, физиолог Павлов, Генри Форд, Билл Гейтс, Рокфеллеры, Гарри Каспаров.

Художники: Рафаэль (Раффаэлло Санти), Леонардо да Винчи, Микеланджело, Пабло Пикассо, Альбрехт Дюрер, Огюст Роден, Питер Пауль Рубенс, Анри Тулуз-Лотрек.

Актеры: Чарли Чаплин, Мэрилин Монро, Грета Гарбо, Брюс Бокслейтнер, Том Круз, Роберт Де Ниро, Дэвид Духовны, Анжелина Джоли, Мила Йовович, Николь Кидман, Джулия Робертс, Брюс Уиллис, Сильвестр Сталлоне, Вупи Голдберг, Деми Мур, Киану Ривз, Хью Джекман, Морган Фриман, Джош Холлоуэй, Билл Мюррэй, Оуэн Уилсон, Тиль Швайгер, Джейсон Стэтхэм, Микки Рурк, Скарлетт Йоханссон, Сара Джессика Паркер, Режиссёр Джеймс Камерон, Антон Камолов.
Музыканты: Никколо Паганини, Людвиг Ван Бетховен, Вольфгант Амадей Моцарт, Фредерик Шопен, Роберт Шуман, Сергей Рахманинов, Сергей Прокофьев, Энрике Карузо, Пол Маккартни, Дэвид Боуи, Мирей Матье, Фил Коллинс, Селин Дион, Боб Дилан, Джими Хендрикс, Рики Мартин, Роберт Плант, Стинг, Эминем, Джорж Майклс.

Писатели и философы: Аристотель, Фридрих Ницше, Франц Кафка, Ганс Христиан Андерсен, Александр Пушкин, Лев Толстой, Владимир Даль, Льюис Кэрролл, Герберт Уэллс, Марк Твен, Николай Лесков.

Спортсмены: Корри Сандерс, Моника Селеш, Мартина Навратилова, Диего Марадона, Бобби Чарльтон, Йохан Круифф, Пеле Рууд Гуллит, Мишель Платини, Марко Ван Бастен, Олег Блохин, Оскар Де Ла Хойя, Мэнни Пакьяо, Ласло Папп...

И многие, многие другие......

Причина самого наличия доминирующей руки окончательно не определена. Пока нет чёткого и однозначного ответа на многие вопросы о леворукости. Ещё не открыты загадки её происхождения, мало известно о психологических и физиологических особенностях левшей, но с уверенностью можно сказать, что леворукость - это индивидуальный вариант нормы.

\section{Левшество: природа и особенности}

Животные имеют намного больше общего с человеком, чем считалось ранее. Ученые убедительно доказали, что не только люди предпочитают чаще использовать одну руку, но и собаки с кошками отдают предпочтение правой или левой лапе, пишет «Культура-ВРН» со ссылкой на Sunday Times.

До недавнего времени считалось, что животные одинаково умело, действуют обеими передними лапами. Но последние исследования позволяют утверждать: собаки и кошки бывают левшами и правшами точно так же, как и люди.

У разных живых существ, процент правшей и левшей, среди особей одного вида может сильно различаться. Так, среди мышей 44\% правшей, 28\% левшей, а остальные - амбидекстры, зато все белые медведи - левши. Примечательно, что даже среди шимпанзе отношение левшей и правшей отличается от существующего у людей. Например, в дикой природе около 2/3 шимпанзе являются левшами. В неволе большинство приматов — правши; возможно, 
это объясняется вынужденным общением с людьми, которые в большинстве своём правши ${ }^{2}$.

Изучение особенностей левшей осложняется тем, что левши вовсе не являются однородной группой. Существуют различные причины левшества, кроме того, встречается «скрытое» левшество. Чтобы разобраться во всем многообразии этих проявлений, прежде всего, необходимо разграничить понятия “леворукость” и “левшество”.

Левша - человек, предпочтительно пользующийся левой рукой в место правой. Люди, являющиеся левшами, в основном, используют левую руку намного чаще, чем правую. Левша преимущественно будет пользоваться левой рукой для личных нужд, приготовления еды и подобных дел. Рука, используемая для письма, не является точным индикатором лево - (право-) рукости. Так, множество левшей пишут правой рукой, используя левую руку для выполнения большинства других задач. Использование левой или правой конечности в качестве ведущей (так называемая, “рукость”) является отражением специфики организации психической деятельности.

Функции каждого полушария головного мозга представляют целостную, законченную систему. В отличие от других парных органов - глаз, рук, ушей - полушария не являются взаимозаменяемыми. Левое - служит для смыслового восприятия и воспроизведения речи, письма, счета, логического, аналитического и абстрактного мышления. Правое - предназначено для пространственно-зрительных функций, интуиции, музыки, ситуативного мышления. Но на деле столь четкого разделения между полушариями не существует.

Казалось бы, организация мозговой деятельности у левшей должна быть такая же, как у правшей, но в зеркальном отражении. Но это совсем не так! Левша устроен и развивается совершенно по другим законам.

У правшей каждое полушарие мозга имеет собственные функции, они находятся в постоянном взаимодействии. Информация извне поступает сначала в правое полушарие, где узнается, «получает образ», а затем уже в левое, где конкретизируется и называется. Правое полушарие (у правшей) преимущественно отвечает за оценку пространственных отношений, воображение, целостное восприятие, оценку

\footnotetext{
${ }^{2}$ Статья «Ученые обнаружили у животных леволапость»,
} http://www.rosbalt.ru/style/2010/05/02/733639.html ритмов и одновременное восприятие нескольких стимулов. Левое полушарие специализируется на оценке временных отношений, конкретизации словесных выражений, чисел, на аналитическом последовательном восприятии, абстрактном и обобщенном мышлении. Правое мозговое полушарие сопряжено в основном с чувствительной сферой, а левое сопряжено с двигательной и речевой сферой. Правое полушарие отвечает за работу левой половины тела, а левое - за работу правой половины тела. У большинства людей доминирует «логическое», левое полушарие, а организующую роль играют энергетические, подкорковые структуры. Внутри полушарий компоненты психических функций тоже достаточно четко локализованы. Например, за пространственные представления и пространственную организацию психических функций отвечает теменная зона левого и правого полушария, а за понимание обращенной речи - височная область левого полушария. У левши оба полушария, как правило, более автономны по своей работе, межполушарные взаимодействия формируются гораздо позже, чем у правши.

У левшей связи между полушариями мозга не столь жесткие, как у «правого» большинства. Поэтому информация в коре головного мозга может обрабатываться медленнее, но это не болезнь, а особенность. У сильного правши другие сложности: жесткие связи между полушариями как бы оставляют мало шансов на свободу творчества, разнообразие.

Таким образом, левшество не сводится к леворукости - преимущественному пользованию левой рукой при выполнении различных действий, обусловленному доминированием правого полушария ${ }^{3}$. Левшество - это предпочтение не только руки, но и ноги, глаза, уха и даже чувствительности левой половины тела. Просто в обычной жизни большинство людей редко обращает внимание на то, какую ногу, ухо или глаз предпочитает человек.

Стоит заметить, что абсолютных левшей - у которых ведущие все парные органы левой стороны тела, - очень мало. Для совершая простых привычных движений выбирается удобный вариант. Например, если вы прислушиваетесь к звукам за стеной правым ухом, заводите часы правой рукой, держите телефонную трубку в правой (кроме ситуаций, когда надо что-то записать), даже вальсируе-

\footnotetext{
${ }^{3}$ М.М. Безруких, “Леворукий ребёнок”. - М., 2001
} 
те в правую сторону - вы чистый правша. В общем, сплошная асимметрия! Каждый пятый выдающийся человек - левша.

Возможности внутреннего мира левшей поистине безграничны. Образы из их внутреннего мира рано или поздно при благоприятной обстановке переносятся ими в реальную действительность в виде художественных, музыкальных и литературных произведений, которые как бы приоткрывают перед нами дверь в мир внутренний, давая возможность почувствовать его завораживающую глубину.

Встречается достаточно примеров, когда человек с задатками незаурядных способностей (левша) при переучивании его работать правой рукой терял все эти способности, гася свою “божественную искру”. Есть исследования, доказывающие, что если вернуться к своей природе и начать писать и вообще все делать левой рукой, то все приобретенные болезни проходят, а человек становится способен творчески реализоваться.

\section{Сравнение явления левшества у человека и кошки}

Кошка, является представителем семейства Felidae - млекопитающих; самый совершенный охотник - отряд хищников ${ }^{4}$.

Англичане говорят, Бог создал кошку, чтобы человек мог постоянно наблюдать красоту в чистом виде.... Египтяне почитали кошек, а богиня радости Бастет, часто изображалась как женщина с кошачьей головой, или как кошка ${ }^{5}$ В мифологии скандинавов, кошка - излюбленное животные Фрейи, языческой богини любви, интересен и тот факт, что богиня передвигается на повозке, в которой запряжены кошки.

Кошек любили и боялись. Всемирную историческую известность получила любимая белоснежная кошка кардинала Ришелье - Мириам. Авраам Линкольн, у которого были 4 кошки в бытность его президентом. При Маргарет Тэтчер в резиденции жил кот - Хэмфри. Благодаря СМИ, литературе и кинематографу, широкую известность в ХХ и XXI веках приобрели кошки и коты президентов

\footnotetext{
${ }^{4}$ А. Э. Брэм, Жизнь животных. «Млекопитающие» - М.: Изд-во Эксимо, 2006, стр.378-379.

${ }^{5}$ Египетская мифология: Энциклопедия. - М.: Изд-во Эксмо, 2002.-592с., илл, ст. 435.
}

США Билла Клинтона- Сокс, премьер-министров Великобритании - Хамфри, Папы Римского Бенедикта XVI - Чико и президента России Дмитрия Медведева - Дорофей. А вот такие герои истории как Юлий Цезарь, Генрих II, Карл ХІ и Наполеон боялись кошек. Исаак Ньютон, великий физик, открывший закон всемирного тяготения, также сделал еще одно открытие. Именно он додумался устроить дверь для кошки в двери дома. Кошки являются единственными животными, которым разрешено входить в православный храм и мусульманскую мечеть.

«Пока она в доме, она ловит мышей и ласкова с детьми, если только дети не слишком больно таскают ее за хвост. Но чуть улучит минуту, чуть настанет ночь и взойдет луна, сейчас, же она говорит: “Я, Кошка, хожу, где вздумается, и гуляю сама по себе” - и бежит в чащу Дикого Леса, или влезает на мокрые Дикие Деревья, или взбирается на мокрые Дикие Крыши и дико машет своим диким хвостом» ${ }^{6}$.

Кошка - индивидуалист, однако требующий определенной социальной коммуникабельности, особенности и суть которой во многом ускользает от понимания человеком. Живя с относительно огромным по размерам и могуществу существом в одном доме, она остается полностью адекватной, психически равноправной и все элементы социальной коммуникабельности в большей мере определяются ею, чем человеком: она принимает только то, что готова и хочет принимать.

Наблюдения показывают, что у животных проявляется альтруизм, чувство юмора, находчивость, привязанность и любовь (которая подчас посильнее и вернее человеческой), они способны тосковать, они могут находить решения новых для них проблем и с каждым разом все лучше их решают. Они способны к творчеству, которое проявляется как в играх, так и в специфической деятельности, никак не связанной с текущими задачами жизнеобеспечения. У них есть системы общения и передачи личного опыта, в том числе использующие вербальные символы. Ряд современных исследований позволяет сделать вывод о гораздо большем сходстве кошек с людьми, чем мы думаем. Результаты сравнения представлены в Таблице №1 «Сходство и различие кошек и человека.

\footnotetext{
${ }^{6}$ Rudyard Kipling, «The cat that walked by himself», http://mau. $\mathrm{ru} / / /$ read/skazka/kipling2.php
} 
Сходство и различие кошек и человека

\begin{tabular}{|c|c|c|}
\hline Критерии сравнения & Человек & Кошка \\
\hline \multirow[t]{2}{*}{ Генетические признаки } & \multicolumn{2}{|c|}{$\begin{array}{l}\text { Геном человека ближе всего оказался геному домашней кошки. Условно говоря, } \\
\text { кошка и человек имеют одинаковый набор генов - } 50000 .\end{array}$} \\
\hline & $\begin{array}{l}\text { Человек имеет } 23 \text { пары хромосом, } \\
\text { кошка - } 19 \text { хромосомных наборов, } \\
\text { схожесть наблюдается в } 16 \\
\text { хромосомных наборах. }\end{array}$ & $\begin{array}{l}\text { Особенности тела кошки, } \\
\text { определяемые наследственно, } \\
\text { непосредственно влияют на } \\
\text { формирование поведенческих } \\
\text { стереотипов (автоматизмов) и этим } \\
\text { отличается от людей. }\end{array}$ \\
\hline \multirow[t]{2}{*}{ Строение головного мозга } & \multicolumn{2}{|c|}{$\begin{array}{l}\text { Головной мозг кошки и человека похож и отличается от мозга собаки. У человека } \\
\text { и кошки области головного мозга, отвечающие за эмоции, идентичны. }\end{array}$} \\
\hline & $\begin{array}{l}\text { Мозг человека разделен на два } \\
\text { полушария каждое из которых } \\
\text { выполняет свою функцию. }\end{array}$ & $\begin{array}{l}\text { Большая часть кошачьего мозга } \\
\text { управляет их гимнастическими, если не } \\
\text { сказать, балетными способностями. }\end{array}$ \\
\hline \multirow[t]{2}{*}{ Механизмы общения } & \multicolumn{2}{|c|}{$\begin{array}{l}\text { У кошки имеются богатый арсенал для невербального общения: хвост и пластика } \\
\text { тела, положение ушей и различные позы, манера держаться и голос, используемый } \\
\text { в обширном диапазоне. }\end{array}$} \\
\hline & $\begin{array}{l}\text { Вербальные и невербальные механизмы } \\
\text { общения людей. }\end{array}$ & $\begin{array}{l}\text { Кошки производят свыше } 60 \text { разных } \\
\text { звуков. Чем больше разговаривать с } \\
\text { кошкой, тем больше мурлыканья и } \\
\text { мяуканья вы услышите от нее в ответ. } \\
\text { Кошки научились с помощью голоса } \\
\text { управлять поведением человека. }\end{array}$ \\
\hline $\begin{array}{l}\text { Мыслительная деятельность, } \\
\text { обработка информации }\end{array}$ & $\begin{array}{l}\text { Существуют научные данные, } \\
\text { подтверждающие способность кошек } \\
\text { мыслить. Наши домашние любимцы } \\
\text { могут, например, запоминать события, } \\
\text { обобщать предметы по каким-либо } \\
\text { признакам, сравнивать что-либо, но } \\
\text { лишь до известной степени. }\end{array}$ & $\begin{array}{l}\text { Обработка информации, поступающей } \\
\text { из глаз в мозг, у кошек происходит } \\
\text { несколько иначе, чем у человека. } \\
\text { Большая часть зрительной информации } \\
\text { у нее приходится на левую затылочную } \\
\text { область зрительной коры больших } \\
\text { полушарий мозга, а не на обе. }\end{array}$ \\
\hline \multirow[t]{2}{*}{ Взаимоотношения } & \multicolumn{2}{|c|}{$\begin{array}{l}\text { Кошка — животное общественное. Домашним кошкам по душе человеческое } \\
\text { общество. }\end{array}$} \\
\hline & $\begin{array}{l}\text { Полярное отношение. Среди нас есть } \\
\text { и те, кто кошек не любит, но всё же } \\
\text { больше среди нас тех, для которых } \\
\text { нет музыки лучше, чем вечернее } \\
\text { мурлыкание питомца. }\end{array}$ & $\begin{array}{l}\text { Кошки, живя среди нас, не считают } \\
\text { себя маленькими людьми. Это мы } \\
\text { для них - большие кошки, что } \\
\text { наносит отпечаток на их поведение по } \\
\text { отношению к людям. }\end{array}$ \\
\hline \multirow[t]{2}{*}{ Внимание и память } & \multicolumn{2}{|c|}{$\begin{array}{l}\text { Как и человек, кошка способна к длительной концентрации внимания на значимом } \\
\text { объекте. }\end{array}$} \\
\hline & $\begin{array}{l}\text { Кошка способна длительное время } \\
\text { наблюдать за тем, что для человека не } \\
\text { представляет никакого интереса. }\end{array}$ & $\begin{array}{l}\text { «Быстрая» память кошки способна } \\
\text { удерживать информацию на } \\
\text { протяжении } 16 \text { часов (собаки } \\
-5 \text { минут). Однако согласно } \\
\text { результатам проведенного в рамках } \\
\text { настоящего исследования опроса } \\
\text { с } 25 \text { респондентами (в том числе } \\
\text { профессиональный заводчики) кошка } \\
\text { помнит события на протяжении более } \\
\text { двух лет. }\end{array}$ \\
\hline
\end{tabular}


Специалисты Королевского университета в городе Белфаст (Queen's University of Belfast) использовали в своем эксперименте домашних котов и кошек (по 21 представителю от каждого пола). Целью исследования было определить, какую лапу предпочитают животные, правую или левую, выполняя задачи переменной трудности.

Зоопсихологи, доктора университета: Сара Миллсопп (Sarah Millsopp) и Дебора Уэллс (Deborah Wells) проводили наблюдения за играми кошек с их хозяевами в домашних условиях.

Игры были специально задуманными: кошке нужно было выполнить 3 задания. Сами питомцы, ни о чем, не догадываясь, просто играли.

Испытания были следующими:

1. Первое задание: перед кошкой ставился кувшин, на его дне был кусочек тунца. Узкое горлышко кувшина позволяло достать тунец, только запустив в него лапу. Специалисты-зоологи отмечали, какая лапа для этого «пошла в ход».

2. Второе задание: хозяева над головой кошки подвешивали верёвочку с мышкой из ткани. А специалисты записывали, какая из лап первой тянулась за мышкой.

3. Третье задание: питомцу предлагали ту же самую мышку, только теперь её потихоньку тянули перед носом кошки. А учёные вновь фиксировали, какая лапа сначала тянулась за игрушкой.

В итоге, на протяжении нескольких дней эксперимента каждой кошкой было сделано около 100 попыток выполнения каждого из заданий. Для предельной чистоты эксперимента хозяева питомцев старались всё время держать «наживку» точно посередине между двумя лапками кошки.

При подсчёте результатов стало ясно, что во время 2-го и 3-го задания животные в равной степени часто тянулись и левой и правой лапками. А при 1-м испытании (с тунцом в кувшине) почти всегда участвовала одна и та же лапка.

Доктор Дебора Уэллс говорит: “Я думаю, что многое зависит от сложности выполняемого задания. В одном задании питомец готов применить обе лапы, в другом - каждая кошка выбирает только одну лапу. Скорее всего, для того, чтобы быстрее и (или) вернее достать «добычу»7.

7 «Female Cats Are Right-Pawed, Males Are Lefties». Статья
http://dsc.discovery.com/news/2009/07/23/cats-handedness.html
В задании с тунцом самцы предпочитали вытаскивать приманку левой передней лапой, а самки - правой. Следовательно, многое, возможно и строение мозга, обусловлено полом животного.

Среди животных-самцов гораздо больше левшей, чем среди самок - эту особенность в животном мире учёные - зоологи наблюдают уже давно. А эксперименты с домашними кошками подтвердили предыдущие наблюдения.

У семейства кошачьих всё достаточно чётко. По словам доктора Деборы Уэллс, результаты исследований кошек показывают, что имеется две популяции: одна из них предпочитает действовать левой лапой, а другая - правой лапой, при этом различия обусловлены полом животных.

Результаты данного исследования кошек доказывают, что кошки также как и люди, предпочтительно пользуются одной из лап при выполнении трудных задач. Вспомним, что большинство людей может использовать любую руку, чтобы выполнить простые задачи типа открытия двери, и предпочитает определенную руку для задач, требующих точности, как, например, письмо. Более того, исследование перекликается с человеческими статистическими данными: хотя огромное большинство людей является правшами, среди левшей мужчин намного больше, чем женщин. По теории Гешвинда, данный факт связан с подверганием плода мужского пола более высоким дозам тестостерона в утробе матери.

Пока не особо понятно, в чём же польза такого различия между полами. Доктор Уэллс, предполагает, что причина может заключаться в различии поведения самок и самцов: самцам нужно большее охотиться, а самки должны проявлять больше заботы о своём потомстве ${ }^{8}$.

Люди, соизмеряя все вокруг относительно себя и собственных способностей, видят, что животные, как правило, обладают значительно меньшими «человеческими» навыками, и поэтому относят их к заведомо более низкой «ступени развития», забывая про то, что развитие - процесс непрерывный, и он идет параллельно. С позиций антропоцентризма ${ }^{9}$ не

\footnotetext{
8 «Мнение психологов: кошки делятся на правшей и левшей», Статья, http://www.ruscats.ru/2010-01-29-19-17-38/1563-201106-20-11-24-47

${ }^{9}$ Рамонова М.А. Современные трансформации международных политических систем в глобализирующемся мире// Becтник Московского университета. Серия 12. Политические
} 
только животные, но и представители других культур, не знающие языка, представляются примитивными и недоразвитыми, в лучшем случае - забавными и непонимающими простых вещей.

Так непросто дается признание наличия у животных сходных с человеком психических способностей. Внешне они зачастую кажутся явно менее сообразительными. Однако, если бы, например, собака или кошка были столь же “разумными”, они легко могли бы схватывать то, что наблюдают у нас, могли бы найти способ более эффективно общаться с нами, вплоть до выучивания языка.

При этом не вызывает недоумение то, насколько трудно бывает общаться с представителями другой культуры. Мы способны перенять только то, о чем уже имеем свое представление, что хотя бы в начальных навыках уже заложено в нас.

Bce то, что дано кошке природой в большей мере, чем человеку, является основой развития более эффективных интеллектуальных навыков (развиваемых на основе личной системы значимости), чем человеческие в этих направлениях. Кошка лучше распознает, выделяет и реагирует на звуки даже в очень сложных условиях восприятия, лучше ориентируется в условиях плохой видимости и полного отсутствия видимости, по запаху, она лучший акробат, великолепно ориентируется и находит дорогу и т.п. Кроме того, она эффективно развивает свои навыки во всех направлениях, которые являются для нее важными.

В сравнение с другими животным человек сильно развил и углубил способность к абстрактному мышлению, творческой фантазии, выработки предположений. Это дает огромные преимущества для нахождения удачного варианта поведения в новых условиях, дает возможность эффективно приспосабливаться к новому и осваивать новые предметы и явления.

Очень важный момент: что бы такое стало возможным, человеку необходимо повысить значимость творческого мышления так, чтобы внимание удерживалось на этом, а не соскальзывало во множество стимулов воспринимаемых из окружающего. Для ребенка важно научиться не отвлекаться на ворону, а думать о важном. Поначалу для него это такая же непосильная задача, как и для кошек. Он учится меньше замечать окружающее, намерено притуп-

науки, МГУ, 2010. лять яркость и впечатляемость внешнего за счет большей яркости, притягательности внутреннего. Он жертвует непосредственной радостью жизни от окружающего ради внутреннего творческого мышления. Зато кошка неизмеримо более точно и ловко реагирует на то, что воспринимает непосредственно. И, в том числе, умеет использовать все то, что исходит от человека.

Кошка, как и человек, в ходе развития последовательно минует череду критических этапов созревания, в каждом из которых формируется очередная иерархия механизмов поведенческой адаптации. На самом первом из них формируются наследственно предопределяемые структуры мозга, на основе которых в последующем формируются особенности психической организации поведения, характерные для кошки. Как и у человека (и любого другого высшего животного) лишение восприятия необходимых для формирования этих особенностей признаков в текущем критическом периоде развития, навсегда лишает существо возможности их эффективного использования в дальнейшем.

С огромной эффективностью и в короткие сроки кошка, используя игровой режим отработки поведенческих программ, переводит первоначально осознаваемые фазы движений в неосознаваемые автоматизмы, которые становятся стереотипами поведения, но с возможностью их корректировки всякий раз, когда обнаруживается нечто новое в условиях, сопровождающие важный момент в поведенческом акте. В таком случае опять используется сознание для творческого нахождения наиболее выгодного варианта на основе уже имеющегося прежнего опыта, дающего возможности прогнозировать с различной степенью уверенности. Роль сознания на каждом таком этапе заканчивается оценкой результата проверки варианта поведения на практике. После этого сознание может перейти в область следующего по новизне-значимости объекта внимания, а прежняя область остается активной неосознаваемой ${ }^{10}$.

\section{Заключение}

Психологи во всем мире, изучая проблему леворуких людей, в первую очередь детей, в том числе и переученных, пришли к неутешительным выво-

\footnotetext{
${ }^{10}$ А. Хохлов, «Неврология кошек», http://www.scorcher.ru/ art/cats/cats1.php
} 
дам: ВСЕ левши постоянно находятся в состоянии дискомфорта, а отсюда - стресса. Ежеминутно сталкиваясь с приборами, механизмами, различными приспособлениями, кухонной утварью и пр., “заточенными” под правую руку, левша вынужден постоянно осмысливать те свои действия, которые “правши” осуществляют автоматически. Левша постоянно контролирует все мелочи своего быта: как ловчее снять с огня “турку”, у которой носик под правую руку? Как открыть банку консервов левой рукой, если открывалка “правая”? Как не ошибиться в метро - ведь если вставить карточку левой рукой, то можно автоматически пройти не в тот турникет. Левше неудобно набирать номер на стандартном мобильнике, переводить стрелки на наручных часах, неудобно пользоваться правой мышью на компьютере, правыми ножницами и линейкой. Фотографамлевшам постоянно хочется нажать на кнопку фотоаппарата левой рукой, но кнопка находится справа. И таких ситуаций многое множество. Подавленная “леворукость” немного снижает двигательную активность, ведет к небольшому замедлению реакции. В повседневной жизни это почти незаметно, но переученный левша в постоянном “напряге”. Все металлообрабатывающие станки - так же, как, к примеру, зубоврачебные кресла, сделаны для праворуких. Получается, что некоторые профессии левшам недоступны или даются с трудом.

Большинство обитателей правого мира не обращают внимания на проблемы леворуких людей, так как окружающая среда не содержит внутреннего противоречия и не предопределяет необходимость постоянного контроля за происходящими процессами.

Левши вынуждены адаптироваться и привыкли к этому, поэтому, в результате лучше и быстрее, чем правши, могут найти выход или то, что им нужно, приспосабливаются к любым условиям - левшам это приходится делать с детства и потом не вызывает особых проблем.
Чтобы осознать, как досаждают левшам все эти «мелочи», достаточно сесть за руль автомобиля с правым рулем и попытаться одной левой включить нужную передачу.

В заключение хочется с удовольствием заметить, что терпимость к неодинаковости в нашей стране действительно крепнет вместе с уважением к индивидуальным особенностям, и привитием мысли, что каждый член общества должен получить возможности, благоприятные для развития именно его способностей и задатков, даже если для этого необходимо использовать нетрадиционные пути. Так в продаже уже появляются развивающие тетради, прописи и ножницы для левшей, а по телевидению поздравляют всех телезрителей с Международным днем левшей, который празднуется 13 августа.

“Рост числа левшей, как считают ученые «Univercity College» - медицинского факультета Лондонского университета, - может привести к соответствующему подъему общего интеллектуального уровня общества и даже к появлению настоящих гениев в области математики, искусства и спорта"11.

Но главное, о чем мне хочется сказать. Мир так прекрасен в своем многообразии. Хорошо, что есть правши и левши. Хорошо, что в нашей стране издавна в дружбе и согласии жили русские, евреи, казахи, осетины, турки, украинцы и множество других народов проживающих в нашей стране. История России в отличие от многих стран, достойна своим примером. Изначально, Россия прирастала землями - добровольным присоединением к ней народов.

Пусть в нашей великой стране все люди: правши и левши, кошки и собаки, птиц и, звери - все животные живут в мире и согласии.

Ну и ну! Я часто видела котов без ульбки, подумала Алиса, - но улыбка без кота! Это самая несуразная вещь, которую можно вообразить ${ }^{12}$.

\footnotetext{
${ }^{11}$ Материалы с сайта lefthandersday.com

12 Льюис Кэрролл, «Приключения Алисы в Стране Чудес», http://lib.ru/CARROLL/alisa.txt
} 


\section{Библиография}

1. Безруких М. М. “Леворукий ребёнок”- М., 2001

2. Светлов Р. С. “Левши и правши” - Спб., 2004

3. «Египетская мифология: Энциклопедия». - М.: Изд-во Эксмо, 2002.-592с., илл, ст. 435.

4. Льюис Кэрролл, «Приключения Алисы в Стране Чудес», http://lib.ru/CARROLL/alisa.txt

5. Rudyard Kipling, «The cat that walked by himself», http://mau.ru///read/skazka/kipling2.php

6. А. Э. Брэм, Жизнь животных. «Млекопитающие» - М.:Изд-во Эксимо, 2006-960с., илл ст. 378-379. http:// www.e-reading.org.ua/bookreader.php/1004156/Brem_-_Zhizn\%27_zhivotnyh_Tom_I_Mlekopitayushchie. html

7. «Концепции современного естествознания». Под редакцией Л. А. Михайлова. Гл. 10

8. http://www.gumer.info/bibliotek_Buks/Science/mihail/index.php

9. «Ученые обнаружили у животных леволапость». Статья http://www.rosbalt.ru/style/2010/05/02/733639.html

10. «Female Cats Are Right-Pawed, Males Are Lefties». Статья http://dsc.discovery.com/news/2009/07/23/catshandedness.html

11. Хомская Е.Д., Батова Н.Я. «Мозг и эмоции (нейропсихологическое исследование)». М.: Изд-во МГУ, 1992. c. 6-67

12. Рамонова М.А. Современные трансформации международных политических систем в глобализирующемся мире// Вестник Московского университета. Серия 12. Политические науки, МГУ, 2010

13. Брагина Н.Н., Доброхотова Т.А. «Функциональная асимметрия человека». — М., 1988.

14. «Асимметрия мозга и динамика знаковых систем «// Иванов Вяч. Вс. Избранные труды по семиотике и истории культуры. Том І. - М.: «Языки русской культуры», 1999

15. «Зоопсихология и сравнительная психология». Материалы с сайта: http://www.ido.rudn.ru/psychology/ animal_psychology/1.html

16. А. Хохлов. Неврология кошек. http://www.scorcher.ru/art/cats/cats1.php

17. «Приручение кошки». Перевод: Т.А. Митина

18. http://goodnewsanimal.ru/news/priruchenie_koshki/2011-08-27-440

19. Томас С. Элиот. «Практическое котоведение». http://www.blackmile.ru/index.shtm?poem/bigsp/catrus

20. Материала с сайта http://www.levshei.net/

21. Материалы с сайта http://www.zooclub.ru/cats/73.shtml

22. Материалы с сайта http://wildlifeandwildanimals.narod.ru/vvedenie/

23. Материалы с сайта ru.wikipedia.org

24. Материалы с сайта lefthandersday.com

25. Материалы с сайта anythingleft-handed.co.uk

26. Материалы с сайта http://zhurnal.lib.ru/w/wolkow_m_m/wwolkowmmsilver2.shtml

\section{References (transliteration)}

1. Bezrukikh M. M. "Levorukiy rebenok" - M., 2001

2. Svetlov R. S. "Levshi i pravshi" - Spb., 2004

3. «Egipetskaya mifologiya: Entsiklopediya». - M.: Izd-vo Eksmo, 2002.-592s., ill, st. 435.

4. L'yuis Kerroll, «Priklyucheniya Alisy v Strane Chudes», http://lib.ru/CARROLL/alisa.txt

5. Rudyard Kipling, «The cat that walked by himself», http://mau.ru///read/skazka/kipling2.php

6. A. E. Brem, Zhizn' zhivotnykh. «Mlekopitayushchie» - M.:Izd-vo Eksimo, 2006-960s., ill st.378-379. http:// www.e-reading.org.ua/bookreader.php/1004156/Brem_-_Zhizn\%27_zhivotnyh_Tom_I_Mlekopitayushchie. html

7. «Kontseptsii sovremennogo estestvoznaniya». Pod redaktsiey L. A. Mikhaylova. Gl. 10

8. http://www.gumer.info/bibliotek_Buks/Science/mihail/index.php

9. «Uchenye obnaruzhili u zhivotnykh levolapost'». Stat'ya http://www.rosbalt.ru/style/2010/05/02/733639.html 
10. «Female Cats Are Right-Pawed, Males Are Lefties». Stat’ya http://dsc.discovery.com/news/2009/07/23/catshandedness.html

11. Khomskaya E.D., Batova N.Ya. «Mozg i emotsii (neyropsikhologicheskoe issledovanie)». M.: Izd-vo MGU, 1992. s. 6-67

12. Ramonova M.A. Sovremennye transformatsii mezhdunarodnykh politicheskikh sistem v globaliziruyushchemsya mire// Vestnik Moskovskogo universiteta. Seriya 12. Politicheskie nauki, MGU, 2010

13. Bragina N.N., Dobrokhotova T.A. «Funktsional'naya asimmetriya cheloveka». — M., 1988.

14. «Asimmetriya mozga i dinamika znakovykh sistem «// Ivanov Vyach. Vs. Izbrannye trudy po semiotike i istorii kul’tury. Tom I. - M.: «Yazyki russkoy kul’tury», 1999

15. «Zoopsikhologiya i sravnitel'naya psikhologiya». Materialy s sayta: http://www.ido.rudn.ru/psychology/animal_ psychology/1.html

16. A. Khokhlov. Nevrologiya koshek. http://www.scorcher.ru/art/cats/cats1.php

17. «Priruchenie koshki». Perevod: T.A. Mitina

18. http://goodnewsanimal.ru/news/priruchenie_koshki/2011-08-27-440

19. Tomas S. Eliot. «Prakticheskoe kotovedenie». http://www.blackmile.ru/index.shtm?poem/bigsp/catrus

20. Materiala s sayta http://www.levshei.net/

21. Materialy s sayta http://www.zooclub.ru/cats/73.shtml

22. Materialy s sayta http://wildlifeandwildanimals.narod.ru/vvedenie/

23. Materialy s sayta ru.wikipedia.org

24. Materialy s sayta lefthandersday.com

25. Materialy s sayta anythingleft-handed.co.uk

26. Materialy s sayta http://zhurnal.lib.ru/w/wolkow_m_m/wwolkowmmsilver2.shtml 